\title{
Marine landscape shapes hybrid zone in a broadcast spawning bivalve: introgression and genetic structure in Canadian west coast Mytilus
}

\author{
J. L. Shields ${ }^{1}$, J. W. Heath ${ }^{2}$, D. D. Heath ${ }^{1, *}$ \\ ${ }^{1}$ Great Lakes Institute for Environmental Research, University of Windsor, 401 Sunset Ave, Windsor, Ontario N9B 3P4, Canada \\ ${ }^{2}$ Yellow Island Aquaculture Ltd., 1681 Brook Crescent, Campbell River, British Columbia V9W 6K9, Canada
}

\begin{abstract}
Adult marine mussels are sessile, but their highly dispersive planktonic larval stage plays a critical role in shaping population structure. However, shoreline geography and oceanographic currents can modify the dispersal pattern of pelagic larvae. On Vancouver Island (VI), British Columbia, 3 species of blue mussels (native Mytilus trossulus and introduced M. galloprovincialis and M. edulis) form a localized hybrid zone. Here we genetically mapped the distribution of Mytilus species and populations along VI and the surrounding islands. Using diagnostic species markers and microsatellite loci, we estimated the extent of the Mytilus hybrid zone on VI and measured population differentiation among the observed sites in 2005 and 2006. We predicted that the distribution of non-native genotypes would be mirrored by the microsatellite allelic patterns, which correspond to oceanographic features that reflect barriers to gene flow in the Strait of Georgia. Generally, non-native genotypes were restricted to southern VI and strong microsatellite population structure was detected. The distribution of non-native genotypes reflected patterns of microsatellite allele frequency in the Strait of Georgia. Using a landscape genetics approach, we identified 2 genetic discontinuities, which correspond to oceanographic and hydrographic features of the Strait of Georgia. Thus, physical dispersal barriers likely limit the spread of the VI Mytilus hybrid zone; however, additional biological barriers to dispersal must also exist. The VI Mytilus hybrid zone provides an excellent example of complex dispersal patterns in a non-equilibrium system.
\end{abstract}

KEY WORDS: Gene flow barriers $\cdot$ Mytilus $\cdot$ Hybrid $\cdot$ Distribution $\cdot$ Microsatellite $\cdot$ Landscape genetics $\cdot$ Hybrid zone maintenance

Resale or republication not permitted without written consent of the publisher

\section{INTRODUCTION}

Gene flow and dispersal capacity are correlated in many organisms (e.g. Burton 1983, Shaklee \& Bentzen 1998). Most marine invertebrates exhibit high fecundity and a pelagic larval stage and, consequently, high levels of dispersal, which are expected to result in little or no detectable population genetic structure (Palumbi 1994). However, selective pressures may reduce the success of long-distance dispersers, resulting in a much lower realized level of gene flow (e.g. in Crassostrea virginica, Reeb \& Avise 1990 and Sebastes auriculatus, Buonaccorsi et al. 2005). Additionally, pelagic larval dispersal may be constrained and directed by oceanic circulation patterns, local hydrodynamic patterns and shoreline topology (Archambault \& Bourget 1999). Physical features may act to limit gene flow by driving local larval retention, facilitating genetic differentiation even in species with high dispersal potential (e.g. Kenchington et al. 2006). Thus, population genetic structure in broadcast spawning marine invertebrates likely results from a combination of selection and barriers to dispersal (Veliz et al. 2006). The effects of selection and physical isolation can be partitioned by examining spatial genetic structure using neutral markers that are not under direct selective pressure 
and, hence, reflect primarily physical barriers to dispersal (Heath et al. 2006).

Despite the expectation for panmixia among coastal invertebrate populations resulting from extensive larval dispersal, the highly intricate benthic topology and hydrology of Canadian west coast waters suggest the possibility of complex pelagic larval dispersal paths, resulting in localized population subdivision. In British Columbia (BC), Canada, the Strait of Georgia is a long $(222 \mathrm{~km})$, narrow $(28 \mathrm{~km})$, deep (50 to $420 \mathrm{~m}$ ) fjord estuary separating Vancouver Island (VI) from mainland BC. The strait is characterized by numerous peninsulas, narrow passes, islands and shallow sill areas, which restrict surface water flow among basins (Herlinveaux \& Tully 1961, Masson \& Cummins 2004). Such flow restriction may, in turn, limit pelagic larval dispersal, resulting in small-scale spatial genetic structure via local retention of larvae. Therefore, in areas such as the Strait of Georgia, the genetic population structure of broadcast spawning marine invertebrates may be defined, at least in part, by the marine landscape.

The most common sedentary marine bivalve with pelagic larvae in the Strait of Georgia is the blue mussel, consisting of 3 sibling species of the genus Mytilus, which occur sympatrically on the east coast of VI and on the surrounding islands (a region henceforth referred to as ' $V I$ '). The native mussel $M$. trossulus is the most abundant and widely distributed and is found intermixed with the non-native mussel species M. galloprovincialis and $M$. edulis. Non-native and hybrid genotypes were first identified along the south-eastern coast of VI in the early 1990s (Heath et al. 1995). Intermittent seeding of $M$. galloprovincialis from aquaculture tenures in Puget Sound and the Strait of Georgia, as well as shipping, likely play a critical role in maintaining hybrid and introgressed genotypes on southern VI (Heath et al. 1995, Shields et al. 2008). Since then, a southern distribution of these genotypes has persisted with a temporally varying abundance, resulting in a dynamic 'hybrid zone' (Heath et al. 1995, Yanick 2002).

Mytilus are broadcast spawners with high fecundity, an extended pelagic larval phase lasting from several weeks to 2 mo (Bayne 1965) and a dispersal capability estimated to range on average from 30 to $60 \mathrm{~km}$ and in some cases >100 km (McQuaid \& Phillips 2000, Gilg \& Hilbish 2003). Such dispersal potential coupled with high non-native genotype survival and growth in the north (Shields et al. 2008) indicates that the distribution of non-native and hybrid mussels should be expanding northward on VI, yet, to date, there is no evidence to suggest this is occurring.

Given the high dispersal capacity of Mytilus, genetic homogeneity and large-scale panmixia were logical predictions; however, the observed spatially restricted hybrid zone on VI was not consistent with these expec- tations. Here, we used species-specific genetic markers to determine the geographical distribution and temporal stability of the Mytilus hybrid zone off VI. Using data from past studies of the VI hybrid zone geographic distribution, we postulated a physical barrier to gene flow between the north and south regions of VI, since the non-native allele distribution does not appear to be extending north (Heath et al. 1995, Yanick et al. 2003). We used microsatellite loci (assumed neutral markers of gene flow) to test for barriers to gene flow between the regions of high and low introgression. Specifically, we used a landscape genetic analytical approach to identify barriers to gene flow (genetic discontinuities) in the study area. We then related the identified gene flow barriers to the marine landscape around VI. Our analysis of the VI mussel population structure provides a remarkable example of substantial barriers to gene flow in a species with very high dispersal potential. Furthermore, our study highlights the potential for the spread of introduced species to be limited by unexpected physical processes that affect successful dispersal.

\section{MATERIALS AND METHODS}

Field sampling. A total of 1433 Mytilus spp. mussels were collected from the underside of docks and from subtidal pilings at 11 sites on the east coast of VI and 2 sites in Vancouver, BC, Canada, in May and June of 2005 ( $\mathrm{n}=809$ ) and 2006 ( $\mathrm{n}=624$ ) (Fig. 1, Table 1). In the summer of 2005, an additional 3 sites (96 mussels) were sampled west of Campbell River, BC, and in 2006 an additional 4 sites (192 mussels) were sampled among the southern Gulf Islands, BC, for a total collection of 1721 mussels over the 2 yr (Fig. 1, Table 1). A small piece of mantle tissue was taken from each mussel for DNA extraction.

DNA extraction. Approximately $50 \mathrm{mg}$ of mantle edge tissue was coarsely chopped and digested in $500 \mu \mathrm{l}$ of lysis buffer $(50 \mathrm{mM}$ Tris $-\mathrm{HCl} \mathrm{pH} 8.0 ; 1.0 \%$ SDS; $25 \mathrm{mM}$ EDTA $)$ and $200 \mu \mathrm{l}\left(20 \mu \mathrm{g} \mathrm{ml}^{-1}\right)$ proteinase $\mathrm{K}$, shaking at room temperature overnight. DNA was then extracted using the Promega WIZARD DNA extraction kit for samples from 2005, while samples collected in 2006 were extracted using a plate-based DNA extraction protocol (see Elphinstone et al. 2003).

The present study consisted of 2 related but independent genetic analyses: the first used speciesspecific markers to map the occurrence of non-native alleles across the study site over 2 sample years. The second addressed questions raised in the first analyses, but used microsatellite DNA markers to test for genetic structure resulting from geographical barriers to gene flow in the study region over both years. For clarity we 


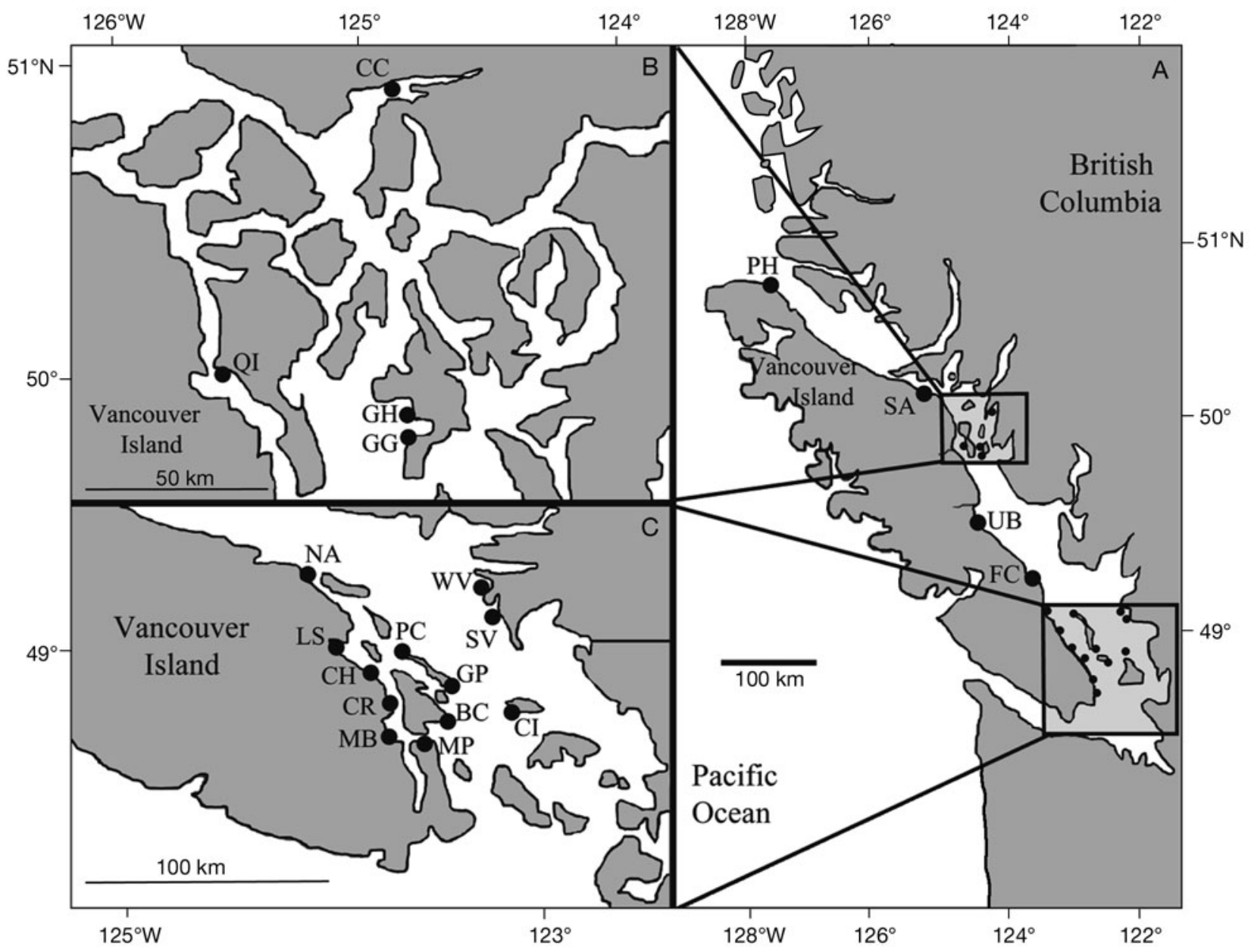

Fig. 1. Mytilus spp. sampling locations off Vancouver Island, British Columbia, and area. (A) Vancouver Island, (B) Discovery Islands, (C) Gulf Islands. Names of sampling locations and year of collection are given in Table 1

have described the 2 approaches separately in the subsections 'Hybrid zone analysis' and 'Genetic structure analysis'.

Hybrid zone analysis. Species identification: The species-marker genotype of each mussel was identified using 2 co-dominant nuclear loci: the polyphenolic adhesive protein ( $G L U$ ) marker developed by Rawson et al. (1996) and the internally transcribed spacer (ITS) marker developed by Heath et al. (1995). These 2 markers identify members of the Mytilus species complex with different degrees of resolution. The ITS marker is a co-dominant Mytilus species marker (see Heath et al. 1995) that generates diagnostic restriction fragment length polymorphism (RFLP) banding patterns capable of distinguishing $M$. trossulus from other members of the Mytilus species complex, as well as hybrids. The ITS species marker is unable to distinguish between $M$. galloprovincialis and $M$. edulis (Heath et al. 1995). Mussels were thus classified as 'native' (M. trossulus), 'non-native' (M. galloprovincialis or M. edulis), or 'hybrid' (M. trossulus $\times M$. gallo- provincialis or $M$. trossulus $\times M$. edulis). $G L U$ is a codominant species marker (see Rawson et al. 1996) that generates polymerase chain reaction (PCR) fragment sizes that are species specific, identifying $M$. trossulus, M. galloprovincialis, $M$. edulis and hybrids between any of the 3 species. GLU PCR fragments were visualized on an automated DNA analyzer (LiCOR 4300).

Data analysis: Individuals were assigned a species genotype based on their 2-locus genotype. Pure types (Mytilus trossulus [MT], M. galloprovincialis [MG], M. edulis [ME]) were identified as consensus homozygous parental genotypes at both loci. First generation hybrid $\left(\mathrm{F}_{1}\right)$ individuals $(\mathrm{MT} \times \mathrm{MG}, \mathrm{MT} \times \mathrm{ME}, \mathrm{MG} \times$ $\mathrm{ME}$ ) were identified as heterozygous at both loci. Backcross and introgressed individuals were identified where the 2 markers disagreed. With only 2 diagnostic markers, error in identifying hybridization and introgression by genotype is unavoidable; however, error is not likely to be a major confounding factor given the relatively large sample sizes of the native genotype class. Differences in the abundance of non-native ver- 
Table 1. Vancouver Island, British Columbia, Canada collection details for Mytilus samples in 2005 and 2006. (-): No samples taken at that site in that year

\begin{tabular}{|c|c|c|c|c|}
\hline \multirow{2}{*}{ Population } & \multicolumn{2}{|c|}{ Sample size } & \multirow{2}{*}{ Latitude $(\mathrm{N})$} & \multirow{2}{*}{ Longitude (W } \\
\hline & 2005 & 2006 & & \\
\hline \multicolumn{5}{|l|}{ North region } \\
\hline Port Hardy (PH) & 66 & 48 & $50^{\circ} 42^{\prime} 44^{\prime \prime}$ & $127^{\circ} 29^{\prime} 20^{\prime \prime}$ \\
\hline Sayward (SA) & 51 & 48 & $50^{\circ} 23^{\prime} 31^{\prime \prime}$ & $125^{\circ} 57^{\prime} 27^{\prime \prime}$ \\
\hline \multicolumn{5}{|l|}{ Central region } \\
\hline Quadra Island (QI) & 66 & 48 & $50^{\circ} 09^{\prime} 33^{\prime \prime}$ & $125^{\circ} 20^{\prime} 10^{\prime \prime}$ \\
\hline Union Bay (UB) & 64 & 48 & $49^{\circ} 35^{\prime} 03^{\prime \prime}$ & $124^{\circ} 53^{\prime} 08^{\prime \prime}$ \\
\hline Gorge Harbour $1(\mathrm{GH})$ & 32 & - & $50^{\circ} 03^{\prime} 04^{\prime \prime}$ & $124^{\circ} 59^{\prime} 43^{\prime \prime}$ \\
\hline Gorge Harbour 2 (GG) & 32 & - & $50^{\circ} 04^{\prime} 26^{\prime \prime}$ & $124^{\circ} 58^{\prime} 54^{\prime \prime}$ \\
\hline Cascade Creek (CC) & 32 & - & $49^{\circ} 59^{\prime} 45^{\prime \prime}$ & $125^{\circ} 13^{\prime} 42^{\prime \prime}$ \\
\hline South Vancouver (SV) & 64 & 48 & $49^{\circ} 16^{\prime} 18^{\prime \prime}$ & $123^{\circ} 10^{\prime} 11^{\prime \prime}$ \\
\hline West Vancouver (WV) & 64 & 48 & $49^{\circ} 22^{\prime} 09^{\prime \prime}$ & $123^{\circ} 17^{\prime} 02^{\prime \prime}$ \\
\hline \multicolumn{5}{|l|}{ South region } \\
\hline French Creek (FC) & 52 & 48 & $49^{\circ} 40^{\prime} 28^{\prime \prime}$ & $124^{\circ} 58^{\prime} 42^{\prime \prime}$ \\
\hline Nanaimo (NA) & 64 & 48 & $49^{\circ} 11^{\prime} 52^{\prime \prime}$ & $123^{\circ} 58^{\prime} 56^{\prime \prime}$ \\
\hline Ladysmith (LS) & 64 & 48 & $48^{\circ} 59^{\prime} 39^{\prime \prime}$ & $123^{\circ} 48^{\prime} 42^{\prime \prime}$ \\
\hline Chemainus $(\mathrm{CH})$ & 52 & 48 & $48^{\circ} 55^{\prime} 35^{\prime \prime}$ & $123^{\circ} 42^{\prime} 52^{\prime \prime}$ \\
\hline Crofton (CR) & 74 & 48 & $48^{\circ} 51^{\prime} 40^{\prime \prime}$ & $123^{\circ} 38^{\prime} 37^{\prime \prime}$ \\
\hline Maple Bay (MB) & 64 & 48 & $48^{\circ} 48^{\prime} 53^{\prime \prime}$ & $123^{\circ} 36^{\prime} 40^{\prime \prime}$ \\
\hline Moses Point (MP) & 64 & 48 & $48^{\circ} 41^{\prime} 23^{\prime \prime}$ & $123^{\circ} 29^{\prime} 00^{\prime \prime}$ \\
\hline Princess Cove (PC) & - & 48 & $48^{\circ} 56^{\prime} 55^{\prime \prime}$ & $123^{\circ} 33^{\prime} 26^{\prime \prime}$ \\
\hline Georgeson Passage (GP) & - & 48 & $48^{\circ} 49^{\prime} 71^{\prime \prime}$ & $123^{\circ} 13^{\prime} 76^{\prime \prime}$ \\
\hline Browning Canal (BC) & - & 48 & $48^{\circ} 46^{\prime} 55^{\prime \prime}$ & $123^{\circ} 15^{\prime} 43^{\prime \prime}$ \\
\hline Cabbage Island (CI) & - & 48 & $48^{\circ} 47^{\prime} 68^{\prime \prime}$ & $123^{\circ} 05^{\prime} 26^{\prime \prime}$ \\
\hline Total & 905 & 816 & & \\
\hline
\end{tabular}

$2.5 \mathrm{mM} \mathrm{MgCl}_{2}$ and $0.5 \mathrm{U}$ Taq DNA polymerase (Applied Biosystems) in a $1 \times$ PCR buffer supplied by the manufacturer. The number of individuals genotyped from each site ranged from 32 to 74 (Supplement 1, available at www.int-res.com/articles/suppl/m399 p211_app.pdf). The PCR protocol consisted of 1 cycle at $95^{\circ} \mathrm{C}$ for 2 min followed by 35 cycles at $95^{\circ} \mathrm{C}$ for $15 \mathrm{~s}, 55^{\circ} \mathrm{C}$ (annealing temperature for all 4 loci) for $15 \mathrm{~s}, 72^{\circ} \mathrm{C}$ for $30 \mathrm{~s}$ followed by a final extension at $72^{\circ} \mathrm{C}$ for $2 \mathrm{~min}$ and a $4^{\circ} \mathrm{C}$ hold. Following PCR, microsatellite alleles were visualized on a LiCOR 4300 DNA analyzer and scored using GENE IMGIR 4.05 (Scanalytics) imaging software. To reduce scoring error, each gel was read twice with an interval of at least 2 wk between readings.

Marker assessment: We used MICROCHECKER (Shipley 2003) software to test for null alleles, private alleles and error due to scoring, stuttering and large allele drop out at the microsatellite loci. Linkage disequilibrium between pairs of microsatellite loci was tested overall

sus native alleles at both species markers between sampling years (2005 \& 2006) at each site were tested using Fisher's exact tests of allele frequency distribution in 'Tools for population genetic analyses' (TFPGA 1.3; Miller 1997). Single-locus exact- $U$-tests of HardyWeinberg equilibrium at the 2 loci were implemented in GENEPOP 3.4 (Raymond \& Rousset 1995). Nonnative allele frequencies were plotted as a cline from south to north along the east coast of VI.

Genetic structure analysis. Microsatellite genotyping: The spatial microsatellite analyses included only the individuals identified as native Mytilus trossulus at both species marker loci, since the inclusion of taxonomically divergent groups invalidates several population genetic analysis assumptions. There were not enough introgressed and non-native individuals to allow separate analyses for those groups. Initially, 7 microsatellite loci (Presa et al. 2002) were screened; however, 3 were subsequently eliminated due to unreliable PCR amplification. Four polymorphic Mytilus microsatellite loci (Mgu3, Mgu5, Mgu6, Mgu7; Presa et al. 2002) were amplified by PCR following conditions specified by Presa et al. (2002) to characterize Mytilus population structure and gene flow on VI. Reactions were carried out in $25 \mu \mathrm{l}$ volumes containing approximately $50 \mathrm{ng}$ DNA template, $32 \mu \mathrm{M}$ dyelabelled forward primer (IR-700, IR-800; NWG Biotech), $0.5 \mu \mathrm{M}$ reverse primer, $200 \mu \mathrm{M}$ of each dNTP, and within populations using GENEPOP 3.4 (Raymond \& Rousset 1995). We tested for departure from Hardy-Weinberg equilibrium (HWE) within each population for each locus using GENEPOP 3.4 (Raymond \& Rousset 1995). Basic descriptive statistics: number of alleles, expected and observed heterozygosity $\left(H_{\mathrm{e}}, H_{\mathrm{o}}\right)$ were compiled for the microsatellite markers using ARLEQUIN 3.11 (Schneider et al. 2000). Allele frequency distributions were compared among groups (Mytilus trossulus [north, central and south regions]; M. galloprovincialis; and introgressed $\left[\mathrm{F}_{1}\right.$ and backcross]) at each microsatellite locus and were repre-

Population genetic differentiation: Pairwise Fisher's exact tests of allele frequency distribution differences were used for all sites sampled (2005 and 2006 separately) in TFPGA 1.3 (Miller 1997). Genetic differentiation $\left(F_{\mathrm{ST}}\right)$ according to Weir \& Cockerham (1984) was calculated over all populations, over all loci and on a pairwise basis between populations using GENEPOP 3.4 (Raymond \& Rousset 1995).

Temporal genetic analyses: To test for temporal stability of the VI Mytilus population genetic structure, we used Fisher's exact tests to compare differences in microsatellite allele frequency distributions at the 13 VI sites sampled in 2005 and 2006 in TFPGA 1.3 (Miller 1997). We visualized the relationship between the 2 sample years in genetic structure by plotting the pairsented as separate graphs for 2005 and 2006. 
wise $F_{\mathrm{ST}}$ values in 2005 against the $F_{\mathrm{ST}}$ values in 2006. If the pairwise $F_{\mathrm{ST}}$ matrix is constant over time, such a plot would be expected to follow a 1:1 relationship. The significance of the matrix correlation was tested using a Mantel test with 1000 iterations in GENEPOP 3.4 (Raymond \& Rousset 1995).

Species effects: $F_{\mathrm{ST}}$ (Weir \& Cockerham 1984) was calculated between mussels identified as native, nonnative and hybrid (based on the species-specific markers) in GENEPOP 3.4 (Raymond \& Rousset 1995) for the 2005 and 2006 microsatellite genotype data. A principal co-ordinates analysis (PCoA) was performed to cluster the species-level microsatellite divergence using GENALEX 6.1 (Peakall \& Smouse 2006). To determine the level of introgression of Mytilus galloprovincialis alleles into $M$. trossulus in the south, we calculated a hybrid index in HINDEX (Buerkle 2005) using M. galloprovincialis as one parental reference group and the northern $M$. trossulus as the second parental reference, as those are the least likely to carry any introgressed alleles.

Spatial genetic analyses: The primary goal of the microsatellite analyses was to identify barriers to gene flow across the sampled area to determine if such barriers could account for the lack of northward spread of the non-native and introgressed mussels. Barriers to gene flow are commonly inferred from genetic divergence based on neutral genetic markers. In the present study, spatial patterns of genetic divergence were determined using landscape genetics analyses, specifically, genetic discontinuity (boundary) analyses and isolation-by-distance models based on the microsatellite genotype data. We identified geographic boundaries of dispersal based on Monmonier's algorithm (Monmonier 1973) and visualized genetic distances between sample sites in relation to their geographical position without defining populations in advance. UTM (Universal Transverse Mercator) coordinates for all sample sites were used in combination with genetic data to generate a connectivity network of genetic distances based on Delaunay triangulation (Brassel \& Reif 1979). Nei's standard genetic distance $\left(D_{\mathrm{s}}\right)$ was calculated for all pairs of individuals to generate a matrix of genetic distances between samples, which were then associated with each edge of the network using AIS 1.0 (Miller 2005). Monmonier's (1973) algorithm was then applied to this geometric network to identify 'barriers' - areas where genetic differences between pairs of populations are greatest. This approach identifies discontinuities in the genetic distance matrix and allows identification of corresponding geographic and oceanographic features that may drive restrictions of gene flow among populations.

To evaluate the significance of barriers identified by AIS 1.0 (Miller 2005) software, a hierarchical (microsatellite) multilocus analysis of molecular variance
(AMOVA) was used to partition total variance among large-scale regions defined by the barrier analysis, among populations within those regions, and among individuals within populations using ARLEQUIN 3.11 (Schneider et al. 2000). $F_{\mathrm{ST}}$ among AIS-identified regions was estimated using a permutation test in GENEPOP 3.4 (Raymond \& Rousset 1995), and the significance of differences in allele frequency distributions among regions was tested by Fisher's exact tests in TFPGA 1.3 (Miller 1997).

We also tested for an isolation-by-distance (IBD) model of genetic differentiation (as an alternative hypothesis to panmixia) at various spatial scales using geographic distance $(\mathrm{km})$ estimated by: (1) shoreline distance and (2) oceanographic distance (shortest ocean current pathway connecting the sampling locations) versus Nei's $D_{\mathrm{s}}$. The significance of the correlations was tested using a Mantel test with 1000 iterations in GENEPOP 3.4 (Raymond \& Rousset 1995).

\section{RESULTS}

\section{Hybrid zone analyses}

The pure native Mytilus trossulus multilocus genotype was most abundant in both years, making up 95.8\% in 2005 and $93.4 \%$ in 2006 of the total sample (Table 2). Individual sampling sites were dominated by pure $M$. trossulus genotypes, with the lowest frequency at the Ladysmith (LS) site (65.2\% in 2005 and $72.9 \%$ in 2006 ; Fig. 2, Table 2). The frequency of non-native genotypes (across both species marker loci) varied significantly between years at 4 sites (Fig. 2), although overall the abundance of non-native genotype mussels did not statistically differ from 2005 to $2006\left(\chi^{2}{ }_{(2)}=7.37, \mathrm{p}>0.05\right)$. In both sampling years, $90 \%$ of non-native genotype mussels were found south of Union Bay (UB; Fig. 2). Both ITS and GLUdeviated from HWE in several populations, resulting from heterozygote deficiency and a paucity of certain expected genotypes (e.g. MT $\times$ ME; Table 2).

\section{Genetic structure analysis (microsatellite markers)}

\section{Marker assessment}

All microsatellite loci were out of HWE after Bonferroni correction in multiple populations in both sample years, and Weir \& Cockerham's (1984) within-population $F_{\text {IS }}$ was significant at multiple loci in all populations in 2005 and 2006 (Supplement 1). Elevated $F_{\text {IS }}$ values are commonly reported among marine bivalves and are often attributed to null allele effects (e.g. scallops, Kenchington et al. 2006 and geoducks, Vadopalas et al. 2004). 
Table 2. Mytilus spp. Genotype proportions of M. trossulus (MT), M. galloprovincialis (MG) and M. edulis (ME) collected in 2005 and 2006 at 2 diagnostic species loci (ITS and GLU). For ITS, ' $\mathrm{N}$ ' is pure native (M. trossulus), 'I' is pure introduced, and ' $\mathrm{H}$ ' is the heterozygote. Names of sampling locations are given in Table 1. (-): No samples taken at that site in that year

\begin{tabular}{|c|c|c|c|c|c|c|c|c|c|c|c|c|c|c|c|c|c|c|c|c|c|}
\hline \multirow{2}{*}{ Locus } & \multirow{2}{*}{$\begin{array}{l}\text { Geno- } \\
\text { type }\end{array}$} & \multirow[b]{2}{*}{$\mathrm{PH}$} & \multirow[b]{2}{*}{ SA } & \multirow[b]{2}{*}{ QI } & \multirow[b]{2}{*}{ UB } & \multirow[b]{2}{*}{$\mathrm{FC}$} & \multirow[b]{2}{*}{ SV } & \multirow[b]{2}{*}{ WV } & \multirow[b]{2}{*}{ NA } & \multicolumn{4}{|c|}{ Sampling location } & \multirow[b]{2}{*}{ MP } & \multirow[b]{2}{*}{$\mathrm{GH}$} & \multirow[b]{2}{*}{ GG } & \multirow[b]{2}{*}{$\mathrm{CC}$} & \multirow[b]{2}{*}{$\mathrm{PC}$} & \multirow[b]{2}{*}{$\mathrm{BC}$} & \multirow[b]{2}{*}{ GP } & \multirow[b]{2}{*}{$\mathrm{CI}$} \\
\hline & & & & & & & & & & LS & $\mathrm{CH}$ & $\mathrm{CR}$ & $\mathrm{MB}$ & & & & & & & & \\
\hline \multicolumn{22}{|l|}{ ITS } \\
\hline \multirow{3}{*}{2005} & $\mathrm{~N}$ & 1.00 & 0.98 & 0.99 & 0.94 & 1.00 & 1.00 & 1.00 & 0.98 & 0.63 & 0.98 & 0.97 & 0.98 & 0.97 & 1.00 & 1.00 & 1.00 & ) - & - & - & - \\
\hline & I & - & 0.02 & - & 0.05 & - & - & - & - & 0.25 & 0.02 & 0.01 & 0.02 & 0.02 & - & - & - & - & - & - & - \\
\hline & $\mathrm{H}$ & - & - & 0.02 & 0.02 & - & - & - & 0.02 & 0.13 & - & 0.01 & - & 0.02 & - & - & - & - & - & - & - \\
\hline \multirow[t]{3}{*}{2006} & $\mathrm{~N}$ & 1.00 & 1.00 & 1.00 & 1.00 & 1.00 & 0.98 & 1.00 & 1.00 & 0.73 & 0.75 & 0.77 & 0.90 & 1.00 & - & - & - & 1.00 & 1.00 & 1.00 & 1.00 \\
\hline & I & - & - & - & - & - & - & - & - & 0.17 & 0.17 & 0.13 & 0.02 & - & - & - & - & - & - & - & - \\
\hline & $\mathrm{H}$ & - & - & - & - & - & 0.02 & - & - & 0.10 & 0.08 & 0.10 & 0.08 & - & - & - & - & - & - & - & - \\
\hline \multicolumn{22}{|l|}{$G L U$} \\
\hline \multirow[t]{6}{*}{2005} & MT & 1.00 & 0.98 & 1.00 & 0.92 & 1.00 & 1.00 & 1.00 & 0.98 & 0.62 & 1.00 & 0.95 & 0.98 & 0.94 & 1.00 & 1.00 & 1.00 & - & - & - & - \\
\hline & MG & - & - & - & 0.03 & - & - & - & - & 0.20 & - & - & - & 0.02 & - & - & - & - & - & - & - \\
\hline & ME & - & - & - & - & - & - & - & - & 0.00 & - & - & - & - & - & - & - & - & - & - & - \\
\hline & $\mathrm{MT} \times \mathrm{MG}$ & - & 0.02 & - & 0.05 & - & - & - & - & 0.13 & - & 0.04 & - & 0.04 & - & - & - & - & - & - & - \\
\hline & $\mathrm{MT} \times \mathrm{ME}$ & - & - & - & - & - & - & - & - & 0.02 & - & - & - & - & - & - & - & - & - & - & - \\
\hline & $\mathrm{MG} \times \mathrm{ME}$ & - & - & - & - & - & - & - & 0.02 & 0.03 & - & 0.01 & 0.02 & - & - & - & - & - & - & - & - \\
\hline \multirow[t]{6}{*}{2006} & MT & 1.00 & 1.00 & 1.00 & 1.00 & 0.98 & 0.98 & 1.00 & 0.98 & 0.73 & 0.77 & 0.77 & 0.92 & 1.00 & - & - & - & 1.00 & 1.00 & 1.00 & 1.00 \\
\hline & MG & - & - & - & - & - & - & - & - & 0.10 & 0.08 & 0.10 & - & - & - & - & - & - & - & - & - \\
\hline & ME & - & - & - & - & - & - & - & - & 0.02 & - & - & - & - & - & - & - & - & - & - & - \\
\hline & $\mathrm{MT} \times \mathrm{MG}$ & - & - & - & - & 0.02 & 0.02 & - & 0.02 & 0.08 & 0.06 & 0.10 & 0.08 & - & - & - & - & - & - & - & - \\
\hline & $\mathrm{MT} \times \mathrm{ME}$ & - & - & - & - & - & - & - & - & 0.02 & - & - & - & - & - & - & - & - & - & - & - \\
\hline & $\mathrm{MG} \times \mathrm{ME}$ & - & - & - & - & - & - & - & - & 0.04 & 0.02 & 0.02 & - & - & - & - & - & - & - & - & - \\
\hline
\end{tabular}

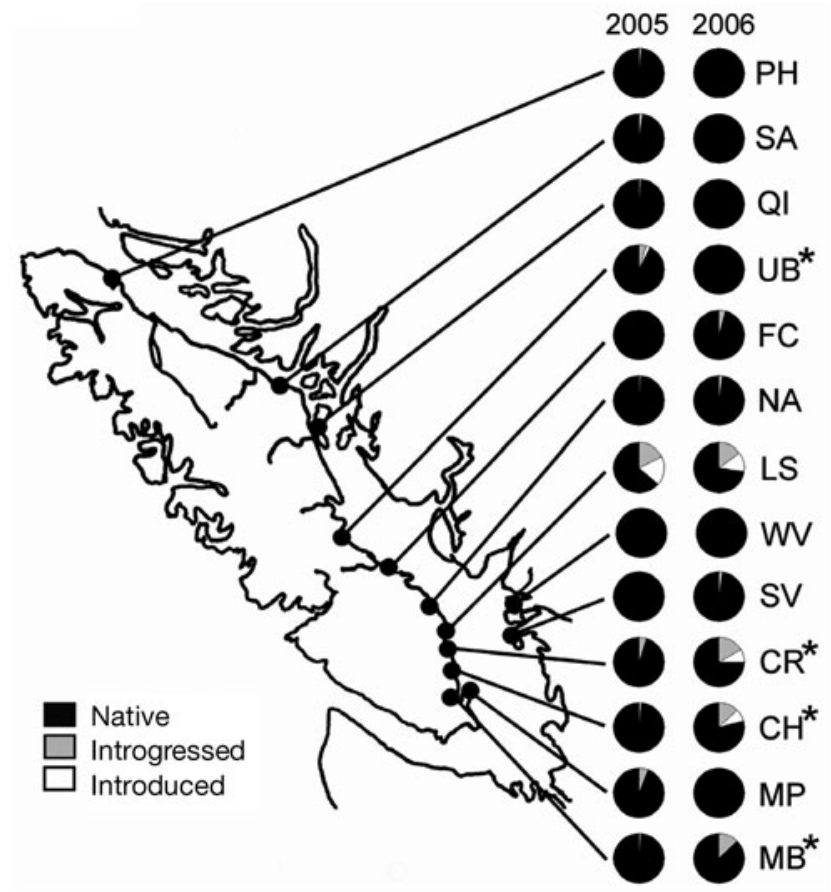

Fig. 2. Mytilus spp. Genotype frequencies at the 13 temporally replicated sites on Vancouver Island based on 2 diagnostic species-specific nuclear genetic markers (ITS and GLU). Allele frequency distributions that were significantly different between years are denoted by an asterisk. Native: $M$. trossulus pure genotype; non-native: $M$. galloprovincialis or $M$. edulis pure genotype; introgressed: first generation hybrid $\mathrm{F}_{1}$ and all higher order backcrosses. Sites that were not replicated in both years are not shown for simplicity, as they were all comprised of $100 \% M$. trossulus alleles (see Table 2). Names of sampling locations are given in Table 1
MICROCHECKER 2.2.3 (Shipley 2003) did not identify stuttering or large allele dropout as contributors to the departure from HWE. However, heterozygote deficit is common in bivalves and may also result when discrete subpopulations are pooled (i.e. Wahlund effect). Hybrid populations violate assumptions of HWE due to varying degrees of assortative mating, interspecific gene flow and selective effects on introgressed genotypes. Since the mussels we identified as 'pure' Mytilus trossulus likely include some introgressed individuals that were not detected using only 2 species-specific markers, all calculations and analyses that assume HWE must be interpreted with caution. However, methods based on genotype frequencies are less sensitive to departures from HWE (Kenchington et al. 2006). Significant linkage disequilibrium was found between Mgu5 and Mgu6 across all populations in both 2005 and 2006 ( $p=0.03$ in both years). Despite linkage disequilibrium, these loci provide additional information as each contains different repeat motifs (tetranucleotide repeat vs. trinucleotide repeat) and thus mutate at different rates. No other loci showed significant linkage disequilibrium. All 4 loci were polymorphic, with the number of alleles ranging from 3 to 37 in 2005 and from 2 to 47 in 2006 (Fig. 3). The frequency of private alleles at individual sites never exceeded 0.05. Nine sites (Crofton, CR; Moses Point, MP; Quadra Island, QI; Gorge Harbour 1, GH; Gorge Harbour 2, GG; Cascade Creek, CC; Princess Cove, PC; Browning Canal, BC; and Georgeson Passage, GP) had no private alleles. Microsatellite allele frequencies are given in Supplement 2 (available at www.intres.com/articles/suppl/m399p211_app.pdf). 

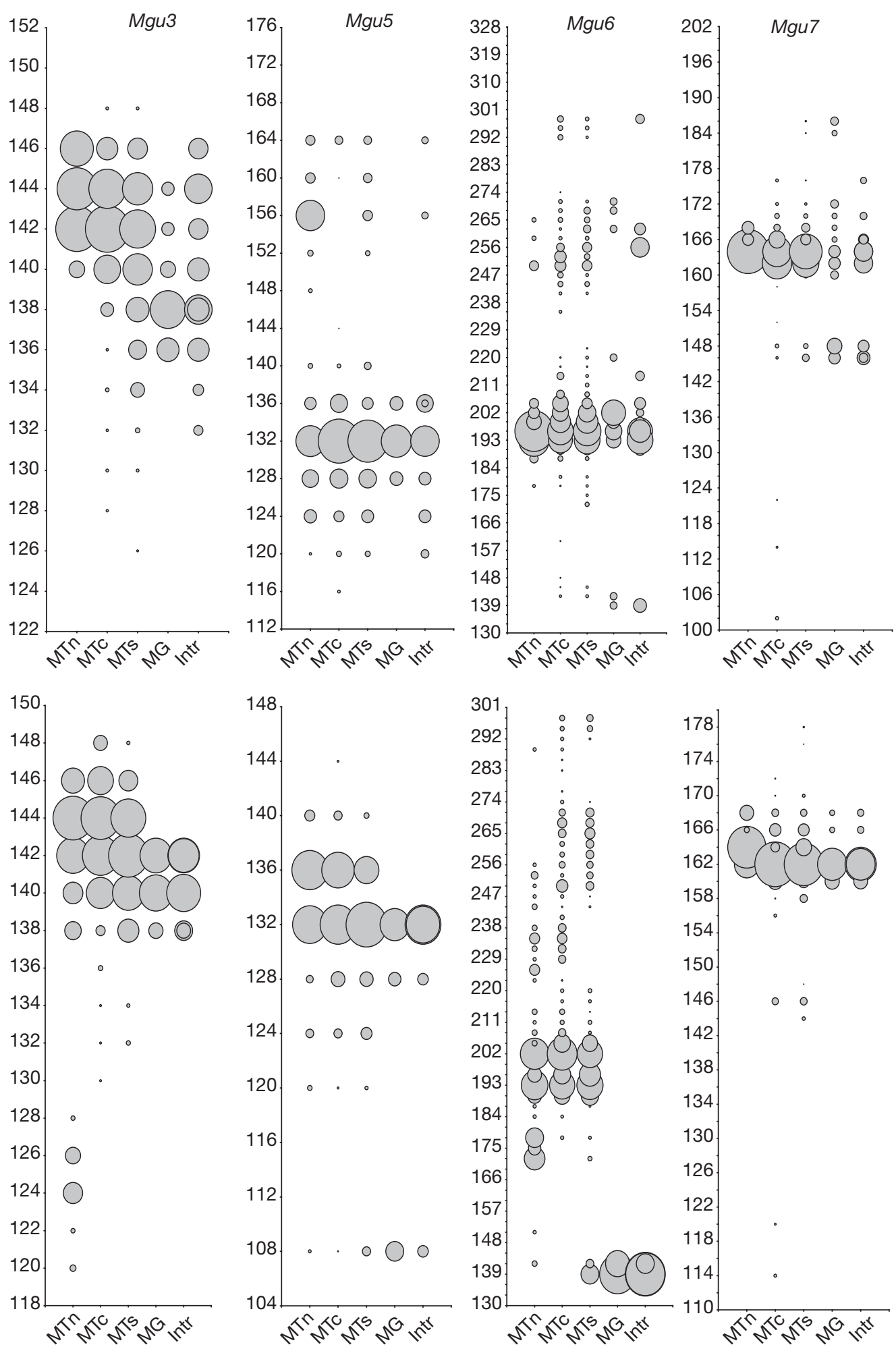

Fig. 3. Mytilus spp. Microsatellite allele frequency distributions. Each circle is 1 allele and its size represents the frequency of that allele in the respective population (MTn, MTc, MTs: $M$. trossulus from the north, central and south regions; MG: M. galloprovincialis; Intr: hybrid and backcross) in (A) 2005 and (B) 2006 for the 4 microsatellite loci labelled. Pooled population sizes in 2005: $\mathrm{MTn}=116, \mathrm{MTc}=465, \mathrm{MTs}=289, \mathrm{MG}=14, \mathrm{Intr}=21$; pooled population sizes in 2006: $\mathrm{MTn}=96, \mathrm{MTc}=285, \mathrm{MTs}=394, \mathrm{MG}=16$, Intr $=25$. For exact frequencies see Supplement 2 available at www.int-res.com/articles/suppl/m399p211_app.pdf 


\section{Population genetic differentiation}

Population differentiation based on allelic identity $\left(F_{\mathrm{ST}}\right)$ indicate moderate to high genetic differentiation between populations in both 2005 and 2006 (Supplement 3, available at www.int-res.com/articles/suppl/ m399p211X_app.pdf). Almost all pairwise comparisons showed significant differentiation between populations as estimated by $F_{\mathrm{ST}}$, with values ranging from 0.001 to 0.353 in 2005 and 0.005 to 0.343 in 2006 . The highest inter-population differences were between SA and all other populations in 2005, and between BC and all other populations in 2006. Microsatellite allele frequency distributions differed between years (Fig. 3, Supplement 2).

\section{Temporal analysis}

Pairwise Fisher's exact tests revealed significant temporal variation in microsatellite allele frequency distributions for all comparisons of the 13 VI sites sampled in 2005 and 2006. Furthermore, although the pairwise $F_{\text {ST }}$ estimates in 2005 and 2006 were significantly correlated (Fig. 4; Mantel test, p < 0.05), there is substantial variation over time, and the matrix correlation explained only $8.6 \%$ of the observed temporal variance in pairwise $F_{\mathrm{ST}}$.

\section{Species effects}

The mussels identified as 'pure' Mytilus trossulus and M. galloprovincialis exhibited highly divergent microsatellite allele frequency distribution (exact test: $\left.\mathrm{p}_{2005}<0.0001 ; \mathrm{p}_{2006}<0.0001\right)$ and relatively high and

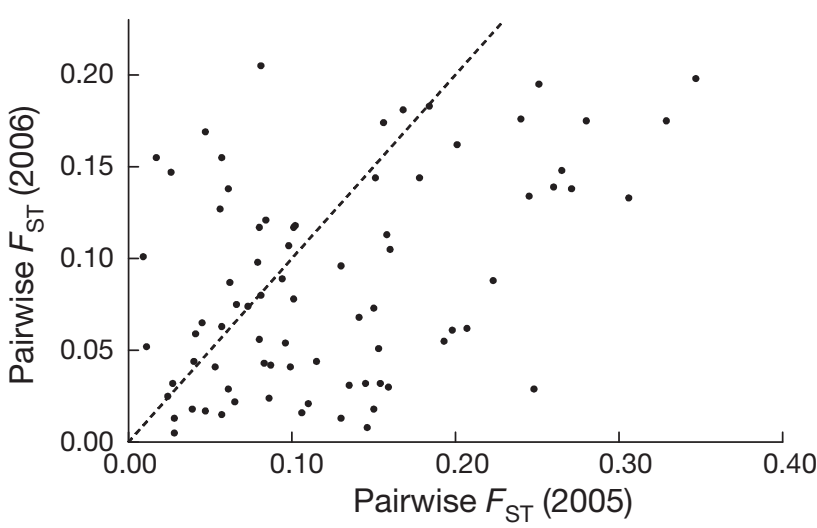

Fig. 4. Mytilus spp. Scatterplot of pairwise $F_{\mathrm{ST}}$ values among sites in 2005 versus 2006. Temporal stability would lead to adherence to the 1:1 line (dashed line). The relationship is significant (Mantel test) at $\mathrm{p}<0.05$. Overall $F_{\mathrm{ST}}$ was higher in 2005 than in 2006 significant $F_{\mathrm{ST}}$ values $\left(F_{\mathrm{ST}(2005)}=0.167 ; F_{\mathrm{ST}(2006)}=0.102\right)$. Principle coordinate analyses based on the microsatellite $F_{\mathrm{ST}}$ matrix separated MG from MT (north, central and south regions), while the introgressed mussels were also divergent (Fig. 5). Our hybrid-index analysis of the 'pure' $M$. trossulus from the southern region indicated that, although some of the mussels were likely not pure, but rather introgressed with the nonnative genome, the proportion of those animals was small (Fig. 6). Furthermore, the observed allele distribution at the 4 microsatellite loci showed little evidence for $\mathrm{MG}$ alleles present in the southern region M. trossulus (Fig. 3). We thus concluded that the group of mussels we identified as 'pure' $M$. trossulus was primarily composed of individuals with little M. galloprovincialis introgressed genome.

\section{Spatial genetic analysis}

Two primary genetic discontinuities were identified by AIS 1.0 (Miller 2005) in both 2005 and 2006, and the geographical positions of those discontinuities were close to identical in the 2 sampling years (Fig. 7), corre-
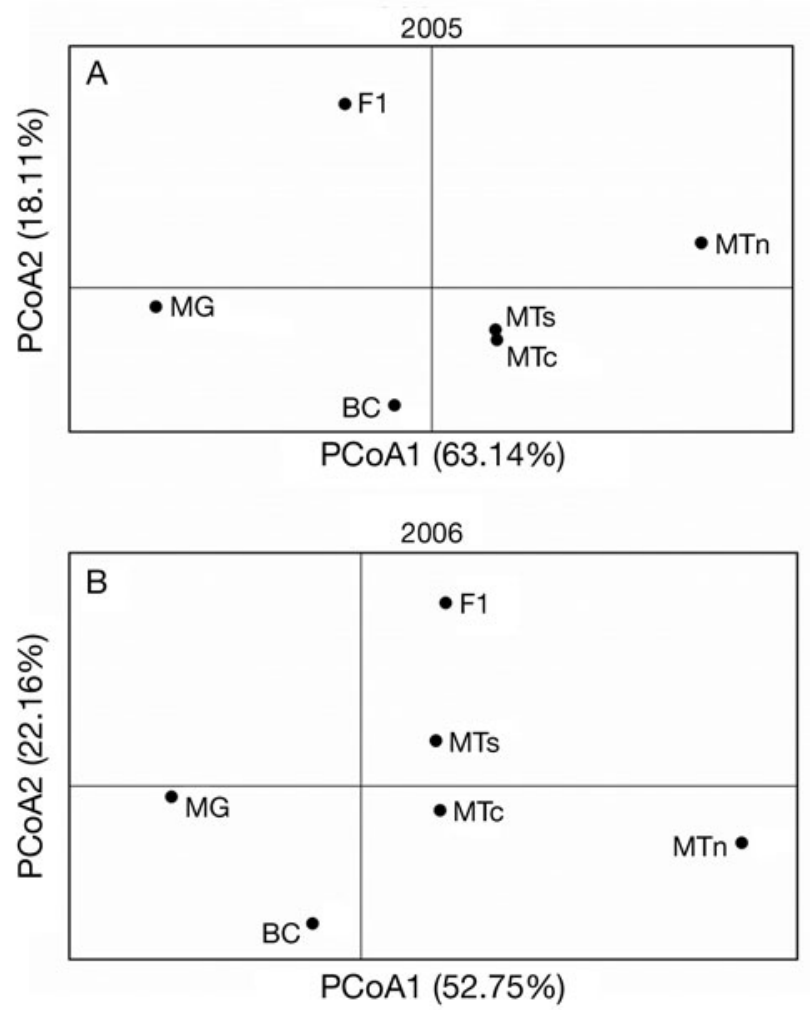

Fig. 5. Mytilus spp. Multidimensional scaling plot of the $F_{\text {ST }}$ (Weir \& Cockerham 1984) matrix values between microsatellite genotypes for all individuals in (A) 2005 and (B) 2006. MT: $M$. trossulus (subscripts $-\mathrm{n}$ : north region; c: central region; $\mathrm{s}$ : south region); MG: $M$. galloprovincialis; $\mathrm{F}_{1}$ : first generation hybrid; $\mathrm{BC}$ : backcrossed 


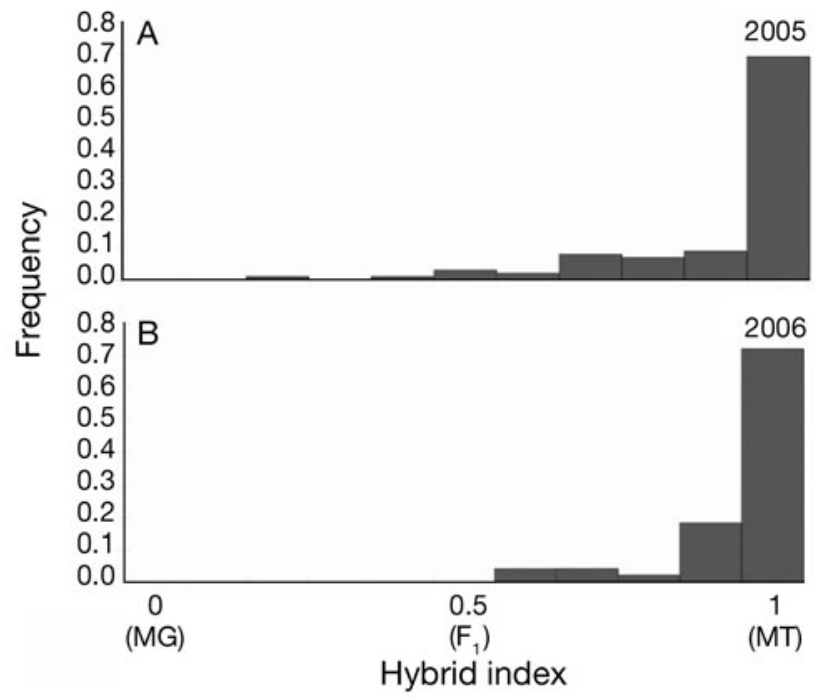

Fig. 6. Mytilus spp. Hybrid index scores for populations collected in (A) 2005 and (B) 2006. The hybrid index indicates the relative probability that the multiple locus genotype of an individual is the result of random mating within each of the parental taxa. The index ranges from 0 to 1 , whereby the 2 extremes occur with high probability in (1) $M$. trossulus and (0) M. galloprovincialis. Individuals identified as 'pure' with ITS and $G L U$ were used as parental input. The analysis was run with all individuals using microsatellite genotype data. $F_{1}$ : first generation hybrid sponding to average summer circulation patterns (Supplement 4, available at www.int-res.com/articles/ suppl/m399p211_app.pdf). Based on those results, barriers to gene flow were inferred, grouping our sample sites into 3 broad geographic regions - north, central and south VI (Fig. 7). The northern region comprised 2 sites on the north coast of VI (Sites Port Hardy (PH) and Sayward (SA); Fig. 7A,B). The central region comprised sites along the central coast of VI and 2 sites in Vancouver on the mainland of BC (Sites QI, GH, GG, CC, UB, South Vancouver (SV) and West Vancouver (WV); Fig. 7A,B). The southern region comprised sites along the south coast of VI, as well as sites among the southern Gulf Islands (Sites French Creek (FC), Nanaimo (NA), LS, Chemainus ( $\mathrm{CH}), \mathrm{CR}$, Maple Bay $(\mathrm{MB}), \mathrm{MP}, \mathrm{PC}, \mathrm{BC}, \mathrm{GP}$ and Cabbage Island (CI); Fig. 7A,B). Our principle coordinate analysis by region strongly supported the AIS results; and the populations within the 3 regions clustered separately (Fig. 7C,D). The north region populations were primarily separated by the first principle coordinate axis (PCoA1; Fig. $7 \mathrm{C}, \mathrm{D})$, while the south and central regions were separated by the second principle coordinate axis (PCoA2; Fig. 7C,D). Small-scale boundaries were also identified that correspond to secondary barriers detected among sites in narrow channels in the southern Gulf Islands,
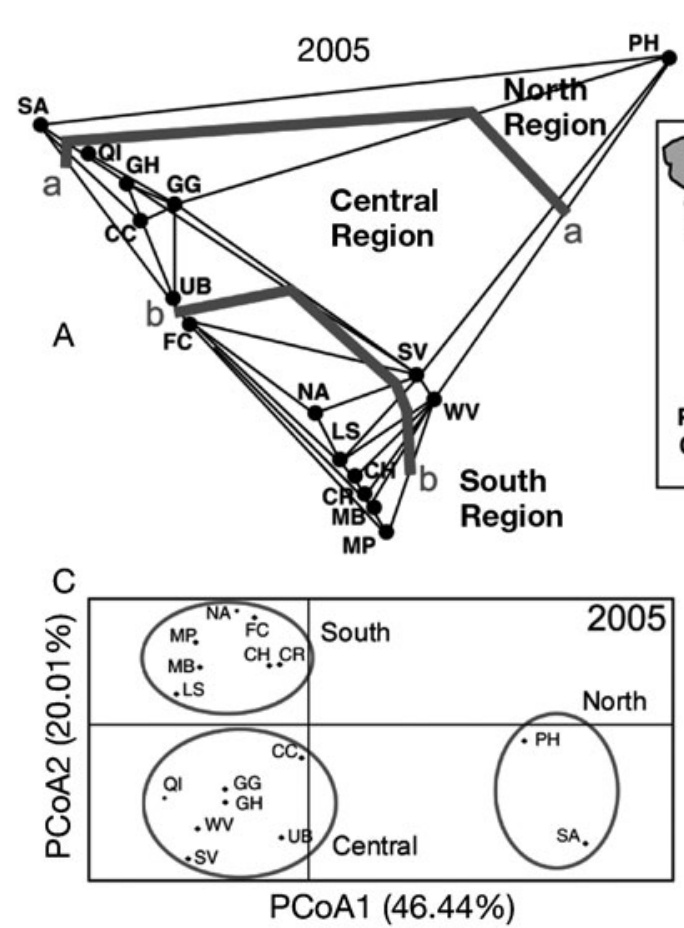
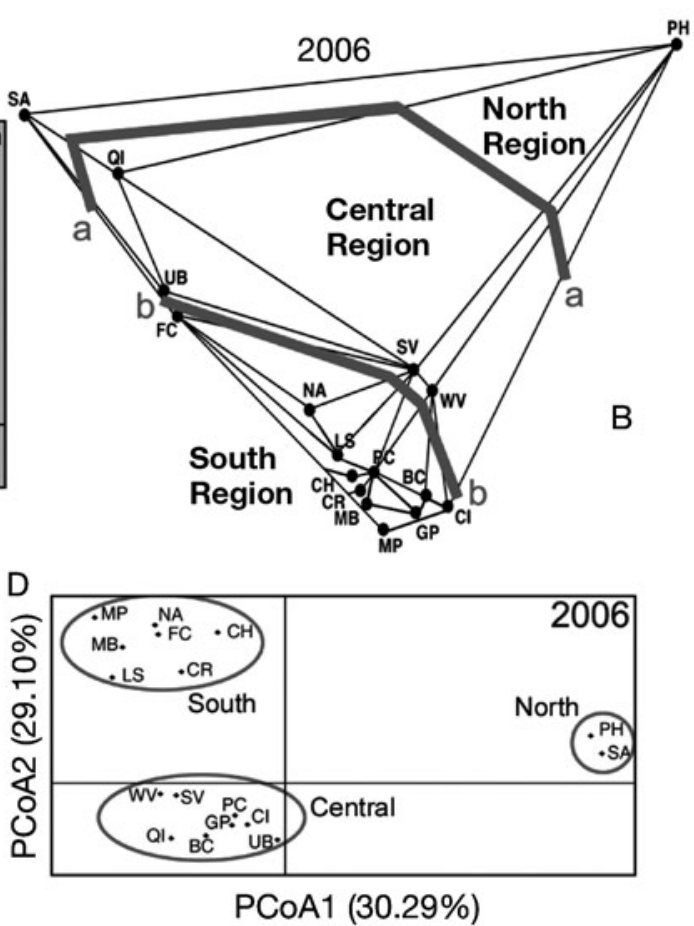

Fig. 7. Mytilus spp. Barrier network identifying areas of limited gene flow as defined by AIS barrier analyses. AIS output-Solid circles represent relative genetic position of individual sampling sites in (A) 2005 and (B) 2006. Putative barriers are labelled a and $b$, represented by thick gray lines. Barriers are overlayed on a map of Vancouver Island for identification of corresponding oceanographic features limiting gene flow. Principal coordinates analysis of the $F_{\mathrm{ST}}$ (Weir \& Cockerham 1984) matrix values among populations are also shown for (C) 2005 and (D) 2006. Names of sampling locations are given in Table 1 
although the location of these barriers was not consistent between sampling years (data not shown). Fisher's exact tests revealed significant genetic differentiation among the 3 large-scale regions defined by the barrier analyses in 2005 and 2006 ( $p \geq 0.001$ in both years). A hierarchical multilocus AMOVA revealed small but significant among-region components, explaining 2.3 and $3.5 \%$ (Table 3 ) of the total variance in 2005 and 2006, respectively. Most of the variance was among individuals within populations $(84.8 \%$ in 2005 and $85.9 \%$ in 2006; Table 3). The AMOVA with regions nested within years showed that the among-year component was substantial ( $3.8 \%$ of the variance; $\mathrm{p}<0.01$; Table 3$)$, but that the among-region variance explained was even greater $(5.8 \%$ of the variance; $\mathrm{p}<$ 0.01; Table 3). Our AMOVA results for the 2 sampling years are remarkably consistent, with the amongregion factor explaining from 2 to $4 \%$ of the genetic variance and the within-region factor explaining from 11 to $13 \%$ of the genetic variance.

Among-region, pairwise $F_{\mathrm{ST}}$ (Weir \& Cockerham 1984) reflect the relatively large differentiation identified by the barrier analysis, with the greatest differentiation between the north and central regions (2005: $F_{\mathrm{ST}}=0.073, \mathrm{p}<0.0001 ; 2006: F_{\mathrm{ST}}=0.091, \mathrm{p}<0.0001$; Table 4). Differentiation between the central and south regions was less pronounced yet still significant (2005: $F_{\mathrm{ST}}=0.012, \mathrm{p}<0.0001 ; 2006: F_{\mathrm{ST}}=0.015, \mathrm{p}<0.0001$; Table 4). A comparison of genetic polymorphism among these 3 regions indicated no significant differ-

Table 3. Mytilus spp. Analysis of molecular variance conducted for the 3 regions defined by the barrier analysis in 2005 and 2006, and across years and regions

\begin{tabular}{|c|c|c|c|c|c|}
\hline Source of variation & $\mathrm{df}$ & SS & $\begin{array}{c}\text { Variance } \\
\text { components }\end{array}$ & $\begin{array}{l}\text { Percent of } \\
\text { variation }\end{array}$ & $\mathrm{p}$ \\
\hline \multicolumn{6}{|l|}{2005} \\
\hline Among regions & 2 & 139.601 & 0.110 & 2.3 & $<0.001$ \\
\hline $\begin{array}{l}\text { Among populations } \\
\text { within regions }\end{array}$ & 15 & 489.907 & 0.605 & 12.9 & $<0.0001$ \\
\hline Within populations & 889 & 3534.492 & 3.976 & 84.8 & $<0.0001$ \\
\hline Total & 905 & 4163.999 & 4.690 & & \\
\hline \multicolumn{6}{|l|}{2006} \\
\hline Among regions & 2 & 131.104 & 0.162 & 3.5 & $<0.001$ \\
\hline $\begin{array}{l}\text { Among populations } \\
\text { within regions }\end{array}$ & 16 & 380.956 & 0.485 & 10.6 & $<0.0001$ \\
\hline Within populations & 799 & 3134.063 & 3.922 & 85.9 & $<0.0001$ \\
\hline Total & 816 & 3646.123 & 4.569 & & \\
\hline \multicolumn{6}{|c|}{ Across years and regions } \\
\hline Among years & 1 & 261.8 & 0.183 & 3.8 & $<0.01$ \\
\hline $\begin{array}{c}\text { Among regions } \\
\text { within years }\end{array}$ & 4 & 302.5 & 0.283 & 5.8 & $<0.01$ \\
\hline Within populations & 1715 & 7500 & 4.37 & 90.4 & $<0.01$ \\
\hline Total & 1720 & 8064 & 4.84 & & \\
\hline
\end{tabular}

Table 4. Mytilus spp. Mean pairwise microsatellite $F_{\text {ST }}$ values among and within regions identified by AIS around Vancouver Island for 2005 (above the diagonal) and 2006 (below the diagonal). Values on the diagonal are the average $F_{\mathrm{ST}}$ among populations within the region across years. All $F_{\mathrm{ST}}$ values are significant at $p<0.001$; exact tests of allele frequency distribution divergence are also all significant $(p<0.0001)$

\begin{tabular}{|llll|}
\hline & North & Central & South \\
\hline North & 0.089 & 0.073 & 0.096 \\
Central & 0.091 & 0.11 & 0.012 \\
South & 0.097 & 0.015 & 0.13 \\
\hline
\end{tabular}

ences in the average number of alleles, observed and expected heterozygosity, or $F_{\mathrm{IS}}$.

No significant IBD pattern was detected overall, or within the 3 regions, in 2005 or 2006 using either geographic or oceanographic distances.

\section{DISCUSSION}

\section{Hybridization and introgression}

Our data show that the non-native mussels Mytilus galloprovincialis persist and hybridize freely with native $M$. trossulus in the Strait of Georgia, BC, Canada. Indeed the frequency of non-native or introgressed mussels is very high at some sites (reaching $>30 \%$ of the sampled mussels), indicative of substantial survival and subsequent reproduction of the non-native mussels. Our results are typical of previous years where the frequency of non-native and introgressed mussels remained high in the southern region over $12 \mathrm{yr}$ of sampling (e.g. Heath et al. 1995; Fig. 8). Although the frequency of non-native alleles varied significantly at a handful of sites between our $2 \mathrm{yr}$ of sampling, the overall incidence of non-native alleles at the species-specific loci remained remarkably consistent. Indeed the frequencies of non-native mussel genotypes in our study (2005: $4.2 \%$; 2006: $6.6 \%$ ) are consistent with those observed in previous years where similar sites were sampled (1994: 6.6\%; 1996: $2.3 \%$; 1997: $9.05 \%$; 1998: $6.3 \%$; mean: $6.1 \%$; Fig. 8). It is not surprising that the non-native genotypes have persisted, since short-term survival of the non-native and introgressed mussels can be very high, even through the summer months when mussel mortality 


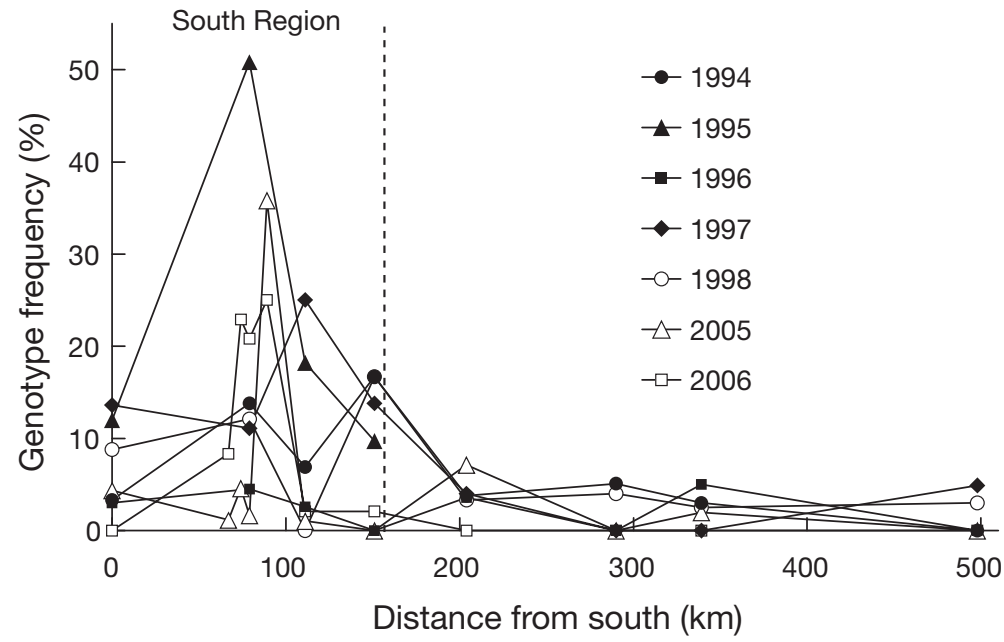

Fig. 8. Non-native Mytilus spp. genotype frequency cline from the most southern sampling site on Vancouver Island along the east coast to the most northerly sampling site. Data are presented for 7 sampling years (1994 to 2006); the vertical line represents the geographical position of the southcentral genetic barrier identified in Fig. 7

\section{Spatial genetic structure}

We found surprisingly high levels of population genetic structure among our sampled Mytilus populations based on variation at 4 microsatellite markers. Indeed, our pairwise $F_{\mathrm{ST}}$ values were approximately 10 times higher than those reported in 2 other microsatellite-based analyses of population genetic structure in Mytilus (M. galloprovincialis; Diz \& Presa 2008, 2009). This anomaly may reflect the non-equilibrium nature of our sampled hybrid zone populations, and possible resulting Wahlund or related effects that inflate our $F_{\mathrm{ST}}$ estimates. Nevertheless, genetic structure has been previously shown to reflect oceanographic features that effectively limit the level of dispersal among marine populations (e.g. Manel et al. 2003, Jorgensen et al. 2005, Kenchington et al. 2006). Indeed, local hydrodynamics may accurately predict the scale and direction of larval dispersal

is normally high (Shields et al. 2008). The unexpected aspect of the VI Mytilus invasion/ hybrid zone is that the non-native genotypes have not increased in abundance, despite apparently high survival and growth potential (Shields et al. 2008). It is even more surprising that the locally high abundance of non-native genotypes found off the southeast coast of VI have not expanded northward (see Fig. 8), again despite empirical evidence for their potentially high fitness in the northern waters of the Strait of Georgia (Shields et al. 2008). Typically, introduced aquatic invertebrates that successfully colonize a region experience relatively rapid range expansion (e.g. Therriault et al. 2005). This is thought to be due to a combination of high dispersive capacity and relatively limited barriers to dispersal (Therriault et al. 2005). However, substantial genetic population structure has been documented in marine taxa expected to experience little or no limits to dispersal (e.g. Palumbi 1994, Ayre \& Hughes 2000, Yanick et al. 2003, Kenchington et al. 2006). In some cases, physical oceanographic features have been postulated to restrict dispersal in marine invertebrates, promoting local larval retention, resulting in reduced gene flow among populations (Hedgecock 1994, Palumbi 1994, Kinlan et al. 2005). However, selection can also contribute to local genetic structuring in marine invertebrates (Yanick et al. 2003). The barrier to dispersal for the non-native VI Mytilus genotypes is a combination of selective and abiotic effects; however, physical oceanographic barriers are likely a key factor in the failure of the non-native Mytilus genotypes to disperse and colonize the waters off northern VI.
(McQuaid \& Phillips 2000, Gilg \& Hilbish 2003, Cowen et al. 2006). In BC, the Strait of Georgia is characterized by warm, low-salinity water with estuarine stratification and circulation (LeBlond 1983), heavily influenced by outflow from the Fraser River (Beamish et al. 1999). Complex hydrodynamic features (Supplement 4) including large-scale circulation reversal, tidal currents and eddies, shallow sills and narrow constrictions can entrain and redistribute buoyant particles, including larvae present throughout the spring and summer, which may promote local larval retention (LeBlond 1983) and limit the northward dispersal of mussels. We used microsatellite DNA markers to identify 3 large-scale geographic regions of genetic connectivity in BC Mytilus: the north coast, the central coast and the south coast. The north coast region is effectively isolated from the central and south coast regions of VI by a series of narrow, shallow channels through the Discovery Islands between the Strait of Georgia and Johnstone Strait. The central coast is less isolated from the south coast; however, a pair of gyres at depths to $290 \mathrm{~m}$ and $15 \mathrm{~km}$ wide within the central Strait of Georgia (cyclonic in the south and anticyclonic in the north; Supplement 4) persists throughout the year, with increased strength during the summer (Masson \& Cummins 2004), which may restrict larval movement between the central and south coast populations. Such a pattern of restricted water movement is consistent with our identified genetic structure among the VI mussels in both 2005 and 2006, and provides a physical barrier explanation for the southern spatial limitation of the VI hybrid zone. However, since micro- 
satellite DNA-based markers often exhibit substantial heterozygote deficits in marine bivalves (e.g. Vadopalas et al. 2004, Kenchington et al. 2006, Cassista \& Hart 2007, Diz \& Presa 2008, 2009), as do our Mytilus microsatellite markers, we cannot rule out the possibility that the genetic structure reported here may be biased by limitations in our markers. Although the abundance of non-native genotypes on southern VI varies over time at individual sites, the region-level abundance did not (Fig. 8), reflecting the genetic barrier locations identified by AIS. The concordance between the regional genetic structure, physical oceanography and distribution pattern of the non-native Mytilus genotypes suggests that physical barriers to dispersal contribute substantially to the observed spatial limitation of the VI hybrid zone.

\section{Selection/genetic swamping}

Although oceanographic features are likely the primary factors driving the observed distribution of the VI hybrid zone, it is unlikely that such processes alone have blocked the spread of non-native mussel genotypes to the north. Over the $12 \mathrm{yr}$ of the VI hybrid zone's known existence, non-native mussel genotypes have been consistently observed at low frequencies in the central and north regions of the Strait of Georgia (Fig. 8). The consistent presence of small numbers of non-native genotypes outside the south region indicates that either some larvae do pass the barriers, or they are introduced through anthropogenic means. In either case, the abundance of non-native genotypes in the northern regions is expected to grow since they thrive when transplanted in cages (Shields et al. 2008); however, the non-native genotypes persist at only very low levels (Fig. 8). This suggests that non-native genotype mussels do not successfully reproduce in the north; thus, some form of selection, perhaps life-stage dependent, must be acting. Alternatively, the few nonnative mussels may backcross with native mussels and eventually become undetectable to our 2-locus genotyping. Although some form of selection or genetic swamping likely plays a role in the hybrid zone dynamics of the non-native VI mussels, marine circulation patterns likely play a dominant role.

\section{CONCLUSIONS}

The role of larval dispersal in determining population genetic structure is critical for marine organisms with sessile adult forms, and hydrographic processes driving larval dispersal can thus be inferred through landscape genetics. When non-indigenous species capable of hybridizing with native species are introduced, accurate prediction of changes in the distribution of the introduced species, as well as hybrid zone dynamics, acquires additional urgency. Geographic patterns of the distribution and introgression of nonnative blue mussels Mytilus spp. on the west coast of Canada cannot be explained by obvious barriers to gene flow; however, using microsatellite genetic makers, oceanographic effects, including currents facilitating local retention, can be inferred. Although oceanographic barriers provide a plausible explanation for the maintenance of the localized hybrid zone along the southern coast of VI, the continued localization of the non-native species must result from additional factors such as reduced larval settlement or limited reproductive success in the north. The application of population genetics using neutral genetic markers to address questions raised in a hybrid zone analyses provides a powerful approach to uncovering mechanisms driving hybrid zone dynamics in marine systems.

Acknowledgements. We thank V. A. Heath, W. G. Wright, J. Wright, A. N. Shields, and T. Colwell for their assistance in sample collections; R. P. Walter for statistical guidance and helpful discussions; M. Foreman, V. Tunnicliffe, and R. Thompson for assistance with oceanographic data and interpretation. We also thank J. Blair and S. Springer for the provision of historical genotype data. This project was funded by the Department of Fisheries and Oceans, Canada, and by Natural Science and Engineering Council of Canada Discovery and Canada Research Chair grants to D.D.H. Yellow Island Aquaculture Ltd. provided funding and logistic support for field sampling.

\section{LITERATURE CITED}

Archambault P, Bourget E (1999) Influence of shoreline configuration on spatial variation of merplanktonic larvae, recruitment and diversity of benthic subtidal communities. J Exp Mar Biol Ecol 238:161-184

Ayre DJ, Hughes TP (2000) Genotypic diversity and gene flow in brooding and spawning corals along the Great Barrier Reef, Australia. Evolution 54:1590-1605

Bayne BL (1965) Growth and delay of metamorphosis of the larvae of Mytilus edulis (L.). Ophelia 2:1-47

Beamish RJ, McFarlane GA, Thomson RE (1999) Recent declines in the recreational catch of coho salmon (Oncorhynchus kisutch) in the Strait of Georgia are related to climate. Can J Fish Aquat Sci 56:506-515

Brassel KE, Reif D (1979) A procedure to generate Thiessen polygons. Geogr Anal 325:31-36

> Buerkle CA (2005) Maximum-likelihood estimation of a hybrid index based on molecular markers. Mol Ecol Notes 5:684-687

Buonaccorsi VP, Kimbrell CA, Lynn EA, Vetter RD (2005) Limited realized dispersal and introgressive hybridization influence genetic structure and conservation strategies for brown rockfish, Sebastes auriculatus. Conserv Genet 6: 697-713

Burton RS (1983) Protein polymorphisms and genetic differentiation of marine invertebrate populations. Mar Biol Lett $4: 132-206$ 
Cassista MC, Hart MW (2007) Spatial and temporal genetic homogeneity in the Arctic surfclam (Mactromeris polynyma). Mar Biol 152:569-579

Cowen RK, Paris CB, Srinivasan A (2006) Scaling of connectivity in marine populations. Science 311:522-527

Diz AP, Presa P (2008) Regional patterns of microsatellite variation in Mytilus galloprovincialis from the Iberian Peninsula. Mar Biol 154:277-286

Diz AP, Presa P (2009) The genetic diversity pattern of Mytilus galloprovincialis in Galician Rias (NW Iberian estuaries). Aquaculture 287:278-286

Elphinstone MS, Hinten GN, Anderson MJ, Nock CJ (2003) An inexpensive and high-throughput procedure to extract and purify total genomic DNA for population studies. Mol Ecol Notes 3:317-320

Gilg MR, Hilbish TJ (2003) The geography of marine larval dispersal: coupling genetics with fine-scale physical oceanography. Ecology 84:2989-2998

Heath DD, Rawson PD, Hilbish TJ (1995) PCR-based nuclear markers identify alien blue mussel (Mytilus spp.) genotypes on the west coast of Canada. Can J Fish Aquat Sci 52:2621-2627

> Heath DD, Shrimpton JM, Hepburn RI, Jamieson SK, Brode SK, Docker MF (2006) Population structure and divergence using microsatellite and gene locus markers in Chinook salmon (Oncorhynchus tshawytscha) populations. Can J Fish Aquat Sci 63:1370-1383

Hedgecock D (1994) Does variance in reproductive success limit effective population sizes of marine organisms? In: Beaumont AR (ed) Genetics and evolution of aquatic organisms. Chapman and Hall, London, p 122-134

Herlinveaux RH, Tully JP (1961) Some oceanographic features of Juan de Fuca Strait. J Fish Res Board Can 18: 1027-1071

Jorgensen HBH, Hansen MM, Bekkevold D, Ruzzante DE, Loeschcke V (2005) Marine landscapes and population genetic structure of herring (Clupea harengus L.) in the Baltic Sea. Mol Ecol 14:3219-3234

Kenchington EL, Patwary MU, Zouros E, Bird CJ (2006) Genetic differentiation in relation to marine landscape in a broadcast-spawning bivalve mollusk (Placopecten magellanicus). Mol Ecol 15:1781-1796

Kinlan BP, Gaines SD, Lester SE (2005) Propagule dispersal and the scales of marine community process. Divers Distrib 11:139-148

LeBlond PH (1983) The Strait of Georgia: functional anatomy of a coastal sea. Can J Fish Aquat Sci 40:1033-1063

Manel S, Schwartz MK, Luikart G, Taberlet P (2003) Landscape genetics: combining landscape ecology and population genetics. Trends Ecol Evol 18:189-197

Masson D, Cummins PF (2004) Observations and modeling of seasonal variability in the Straits of Georgia and Juan de Fuca. J Mar Res 62:491-516

McQuaid CD, Phillips TE (2000) Limited wind-driven dispersal of intertidal mussel larvae: in situ evidence from the plankton and the spread of invasive species Mytilus galloprovincialis in South Africa. Mar Ecol Prog Ser 201: 211-220

Miller MP (1997) Tools for population genetic analysis 3.1: a windows program for the analysis of allozymes and

Editorial responsibility: Philippe Borsa,

Nouméa, New Caledonia molecular population genetic data. Available at: www. marksgeneticsoftware.net/tfpga.htm

Miller MP (2005) Alleles in space (AIS): computer software for the joint analysis of interindividual spatial and genetic information. J Hered 96:722-724

Monmonier MS (1973) Maximum-difference barriers: an alternative numerical regionalization method. Geogr Anal 5: 245-261

Palumbi SR (1994) Genetic divergence, reproductive isolation, and marine speciation. Annu Rev Ecol Syst 25: 547-572

> Peakall R, Smouse PE (2006) GENALEX 6: genetic analysis in Excel. Population genetic software for teaching and research. Mol Ecol Notes 6:288-295

> Presa P, Perez M, Diz AP (2002) Polymorphic microsatellite markers for blue mussels (Mytilus spp.). Conserv Genet 3: 441-443

Rawson PD, Joyner KL, Meetze K, Hilbish TJ (1996) Evidence for intragenic recombination within a novel genetic marker that distinguishes mussels in the Mytilus species complex. Heredity 77:599-607

Raymond M, Rousset F (1995) Genepop (Version 1.2): population genetics software for exact tests and ecumenicism. J Hered 86:248-249

Reeb CA, Avise JC (1990) A genetic discontinuity in a continuously distributed species: mitochondrial DNA in the American oyster, Crassostrea virginica. Genetics 124: 397-406

Schneider S, Roessli D, Excoffier L (2000) Arlequin: a software for population genetics data analysis, Version 2.000. University of Geneva, Geneva

Shaklee JB, Bentzen P (1998) Genetic identification of stocks of marine fish and shellfish. Bull Mar Sci 62:589-621

Shields JL, Barnes P, Heath DD (2008) Growth and survival differences among native, introduced and hybrid blue mussels (Mytilus spp.): genotype, environment and interaction effects. Mar Biol 154:919-928

Shipley P (2003) Micro-checker, Version 2.2.3. University of Hull, Hull

> Therriault TW, Orlova MI, Docker MF, MacIsaac HJ, Heath DD (2005) Invasion genetics of a freshwater mussel (Dreissena rostriformis bugensis) in eastern Europe: high gene flow and multiple introductions. Heredity 95:16-23

Vadopalas B, Leclair LL, Bentzen P (2004) Microsatellite and allozyme analyses reveal few genetic differences among spatially distinct aggregations of geoduck clams (Panopea abrupta Conrad, 1849). J Shellfish Res 23:693-706

Veliz D, Duchesne P, Bourget E, Bernatchez L (2006) Stable genetic polymorphism in heterogeneous environments: balance between asymmetrical dispersal and selection in the acorn barnacle. J Evol Biol 19:589-599

> Weir BS, Cockerham CC (1984) Estimating F-statistics for the analysis of population structure. Evolution 38:1358-1370

Yanick JF (2002) Survival, growth and the possible environmental impacts of introduced blue mussels (Mytilus spp.) in Georgia Strait, British Columbia: implications for mussel aquaculture. MSc thesis, University of Northern British Columbia, Prince George, BC

> Yanick JF, Heath JW, Heath DD (2003) Survival and growth of local and transplanted blue mussels (Mytilus trossulus, Lamark). Aquacult Res 34:869-875

Submitted: October 6, 2008; Accepted: September 24, 2009 Proofs received from author(s): January 7, 2010 